\title{
Terraced Landscapes and Hydrological-Geological Hazards: Innovative Approaches and Future Perspectives
}

\author{
Federico Preti ${ }^{(D}$, Alessandro Errico and Giulio Castelli *(D) \\ Department of Agriculture, Food, Environment and Forestry (DAGRI), Università Degli Studi di Firenze, \\ 50144 Firenze, Italy; Federico.preti@unifi.it (F.P.); errico.alessandro@gmail.com (A.E.) \\ * Correspondence: giulio.castelli@unifi.it
}

check for updates

Citation: Preti, F.; Errico, A.; Castelli, G. Terraced Landscapes and Hydrological-Geological Hazards: Innovative Approaches and Future Perspectives. Water 2021, 13, 1728. https: / doi.org/10.3390/w13131728

Received: 22 June 2021

Accepted: 22 June 2021

Published: 22 June 2021

Publisher's Note: MDPI stays neutral with regard to jurisdictional claims in published maps and institutional affiliations.

Copyright: (C) 2021 by the authors. Licensee MDPI, Basel, Switzerland. This article is an open access article distributed under the terms and conditions of the Creative Commons Attribution (CC BY) license (https:// creativecommons.org/licenses/by/ $4.0 /)$.

\section{Introduction}

In the last few years, terraced landscapes have been receiving renovated interest all over the world (e.g., dry-stone walls named UNESCO heritage in November 2018). Terracing was recognized as a fundamental component of agricultural systems, both for its cultural value as well as for its importance in guaranteeing food production in unfavorable environments.

Such landscapes are among the most evident fingerprints of humankind on terrestrial ecosystems [1], aiming at generating new surfaces available for cultivation in sloping areas, reducing runoff and soil erosion, harvesting and storing rainwater, accumulating biomass by increasing crop production, and restoring ecosystems themselves [2].

The scientific community has been investigating the environmental effects related to terracing for many decades, and, within this framework, hydrological and hydrogeological processes occurring in terraced landscapes. Latest studies showed that terracing represents a radical alteration of pre-existing terrain morphology, thus altering water infiltration and runoff generation processes, and ultimately influencing the entire water cycle from the single terrace up to the slope, catchment, and landscape scales [3,4].

Sound terracing implementation and terraced landscape restoration can contribute to reduce hydrological and hydrogeological hazards, as well as soil erosion and land sliding [5]. On the one hand, this latter effect can be relevant both at the local scale, reducing hazards to agricultural areas, and at the catchment scale, reducing hazards to population and infrastructures located downstream. On the other hand, deteriorated terraced systems, as well as poorly managed or designed terraces, may increase these hazards, and even enhance the triggering of degradation phenomena $[6,7]$.

Recent developments in scientific and technological research techniques have offered the possibility of increasing knowledge of the terracing-hydrogeological hazard nexus, including, for instance, advanced and detailed geomorphological analysis [8,9], and hydraulic, geotechnical, and hydrological modeling [4,10-12].

Given these premises, the aim of the present Special Issue was to gather studies dealing with hydrological-geological risk mitigation given by terraced landscapes, with the potential hazards induced by degraded and/or abandoned terracing, and with effective terrace management strategies. The submission of works showcasing innovative methodologies for the analysis of terraced landscapes and papers on newly implemented terraced systems was encouraged, with a preferred focus on African, South East-Asian, and Latin American countries.

\section{Overview of the Special Issues}

The paper by Pijl et al. [13] presents an innovative analysis of sustainable drainage systems design in a terraced landscape in Valcamonica valley (Italy). These authors considered a high-resolution 3D digital elevation model obtained by an unmanned aerial vehicle (UAV) through photogrammetry. The current terrace system, which was degraded 
after some years of abandonment, was evaluated through the Relative Path Impact Index (RPII) together with three new drainage scenarios, implemented by modifying the elevation model. The methodology allowed a time-efficiency and cost-effectiveness analysis of restoration plans in degraded terraced landscapes.

Mesfin et al. [14] focus their analysis on the effect of drought risk reduction induced by terracing in arid and semiarid areas. The paper studies four newly implemented terraced sites in Ethiopia, highlighting how agricultural terracing can enhance the soil water content in terraced areas. The paper also testifies how terraces implemented with less soil disturbance had better performances related to water retention.

The work by Paliaga et al. [15] takes advantage of a Laser Imaging Detection and Ranging (LIDAR)-based digital elevation model to identify the presence of terraces, including those which have been abandoned, in remote yet internationally famous areas such as the Monte di Portofino Promontory (Italy). They developed a semi-automatic methodology for terrace identification from SAGA-GIS local upslope curvature procedure, testing it in the study area.

Berčič, and Ažman-Momirski [16] developed an innovative parametric design procedure for planning the design of terraced landscapes, with a case study in Slovenia, implemented in the "Grasshopper" plugin in Rhino 3D. The approach proposed was proven to be effective in optimizing the design process of new terraced systems.

The Special Issue also hosted multi-disciplinary research efforts, such as the work by Boselli et al. [17], who studied the dynamics of land abandonment in the terraced landscapes of Anti-Atlas (Morocco) with a system dynamics approach. The analysis highlighted how the abandonment of the terraced agroecosystems in the area is mainly driven by social issues rather than by climatic changes. These results have direct policy implications for land management in the Anti-Atlas, which can be extended to the Southern Mediterranean.

Kurozumi and colleagues [18] presented an innovative investigation about the role of hardpans in rice terraces of the Philippine Cordilleras. Based on field surveys and soil analyses, they showed that the hardpan was not sufficiently developed in areas where organic matter content was high, suggesting organic matter clogging. Such phenomena could hinder the suppression of water infiltration, leading to the collapse of the terrace. Therefore, they suggest checking hardpan consistency before the planting season, since this operation is difficult once the paddy terraces are flooded.

Still within the framework of remote sensing analyses, Cambi et al. [19] proposed a low-cost approach for detecting collapses in terraced landscapes. The approach was based on existing DTMs derived from airborne laser scanner (ALS) data and open source GIS software, and showed how collapses can be related to preferential flow paths, as well as to other parameters.

The paper by Sabir [20] closes the Special Issue, showing how the effects of land abandonment in the terraces of Anti-Atlas (described by Boselli in [17]) lead to a reduction of infiltration in unmanaged terraced landscapes, even after few years. The author suggested immediate action to rehabilitate and restore the socio-ecological systems of terraced areas, to avoid consequent hydrological and hydrogeological hazards.

\section{Final Remarks and Future Perspectives}

The present Special Issue allowed the collection of different contributions from many areas of the world (Figure 1), guaranteeing the heterogeneity of case studies, from ancient to newly established terraced systems, from rice to dryland terraces (Figure 2). 


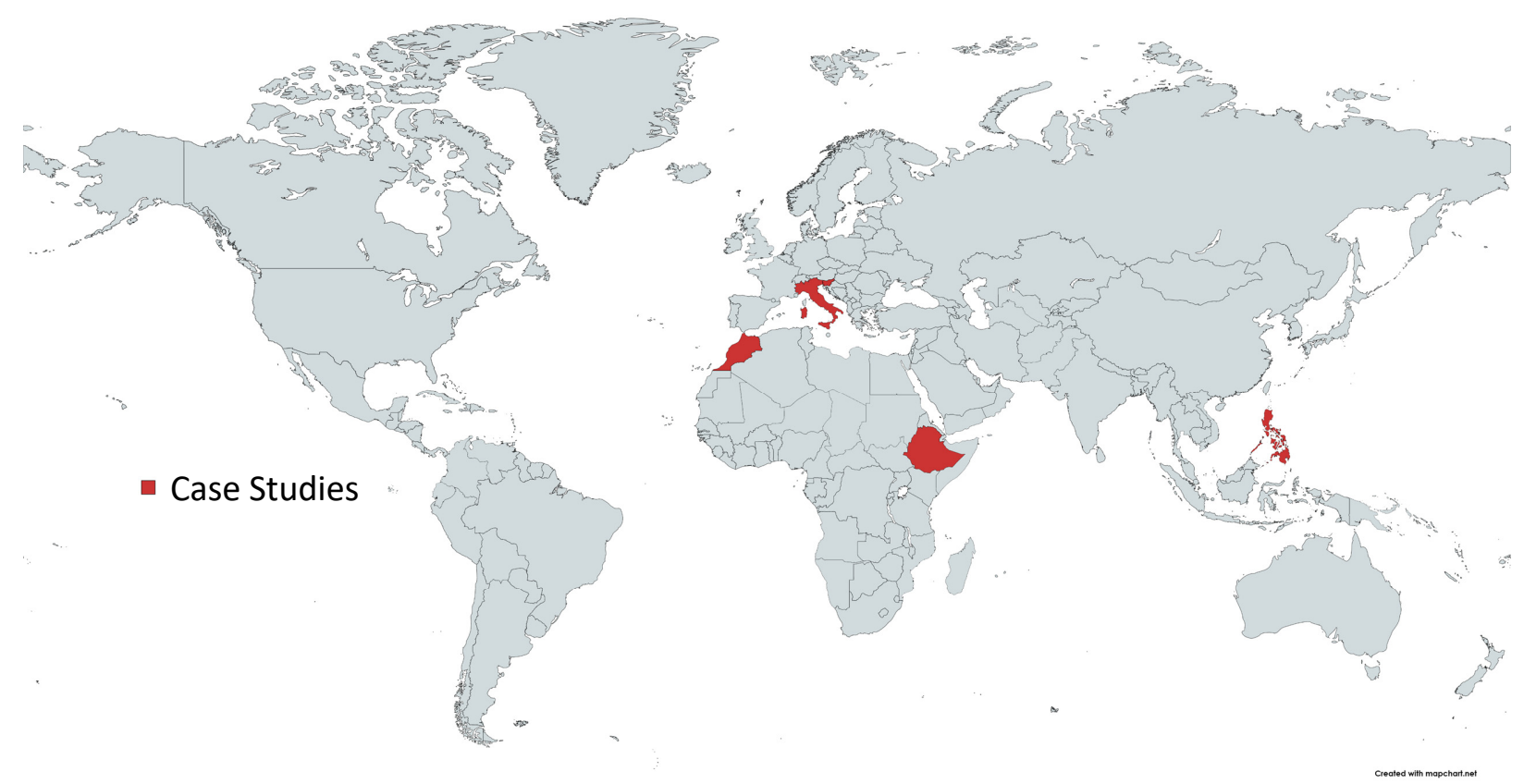

Figure 1. Case studies of the Special Issue were from few countries but well spatially sorted.

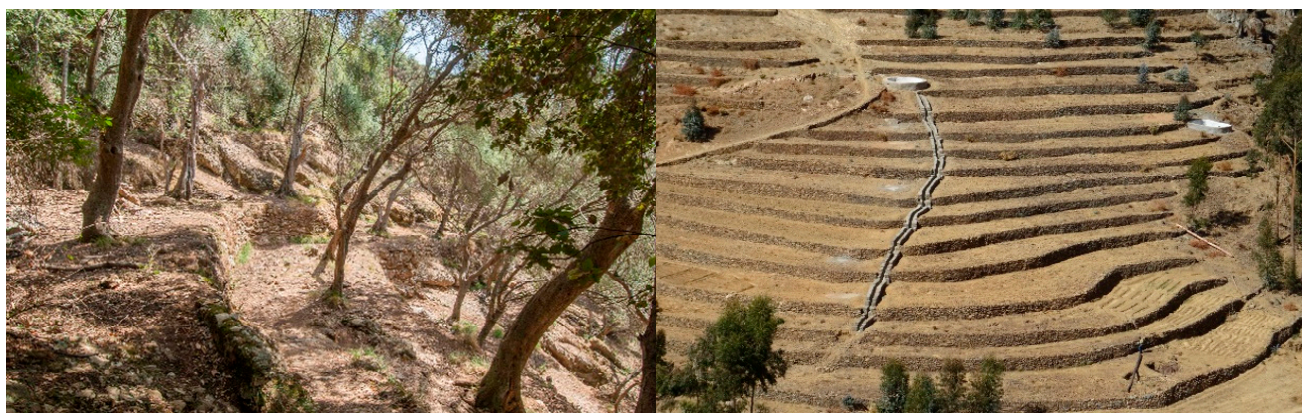

(a)

(b)

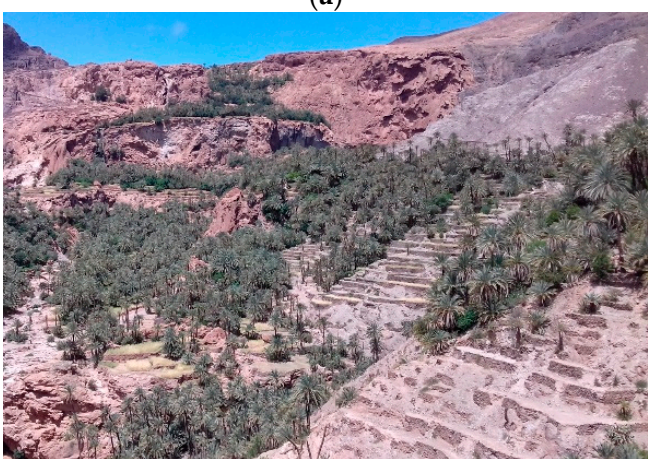

(c)

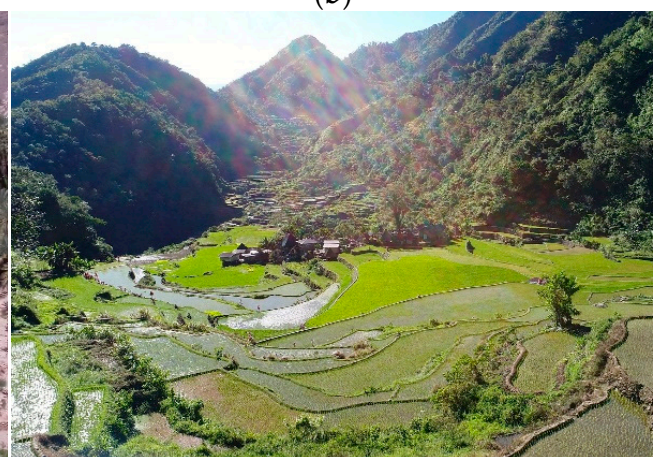

(d)

Figure 2. Case studies of the Special Issue; (a) Terraces in Portofino Promontory (Italy) [15], courtesy of F. Faccini; (b) Newly established terraces in Ethiopia [14], courtesy of S. Mesfin; (c) Terraces of Anti-Atlas (Morocco) [17], courtesy of V.Boselli; (d) Philippine Cordilleras Rice Terraces [18], courtesy of Y. Mori.

Some of the case studies focused on issues related to terrace abandonment (Figure 3) $[13,15,17,19,20]$, which represent an issue at the global scale $[1,6,7]$, while others focused instead on new terrace system implementation [14,16]. Such kinds of research efforts could be considered of particular interest, since, while most of the "historical" terraced landscapes were created a long time ago, they offer the possibility of analyzing the different 
parts of the terracing implementation, highlighting possible errors, their consequences, but also innovative design methodologies.

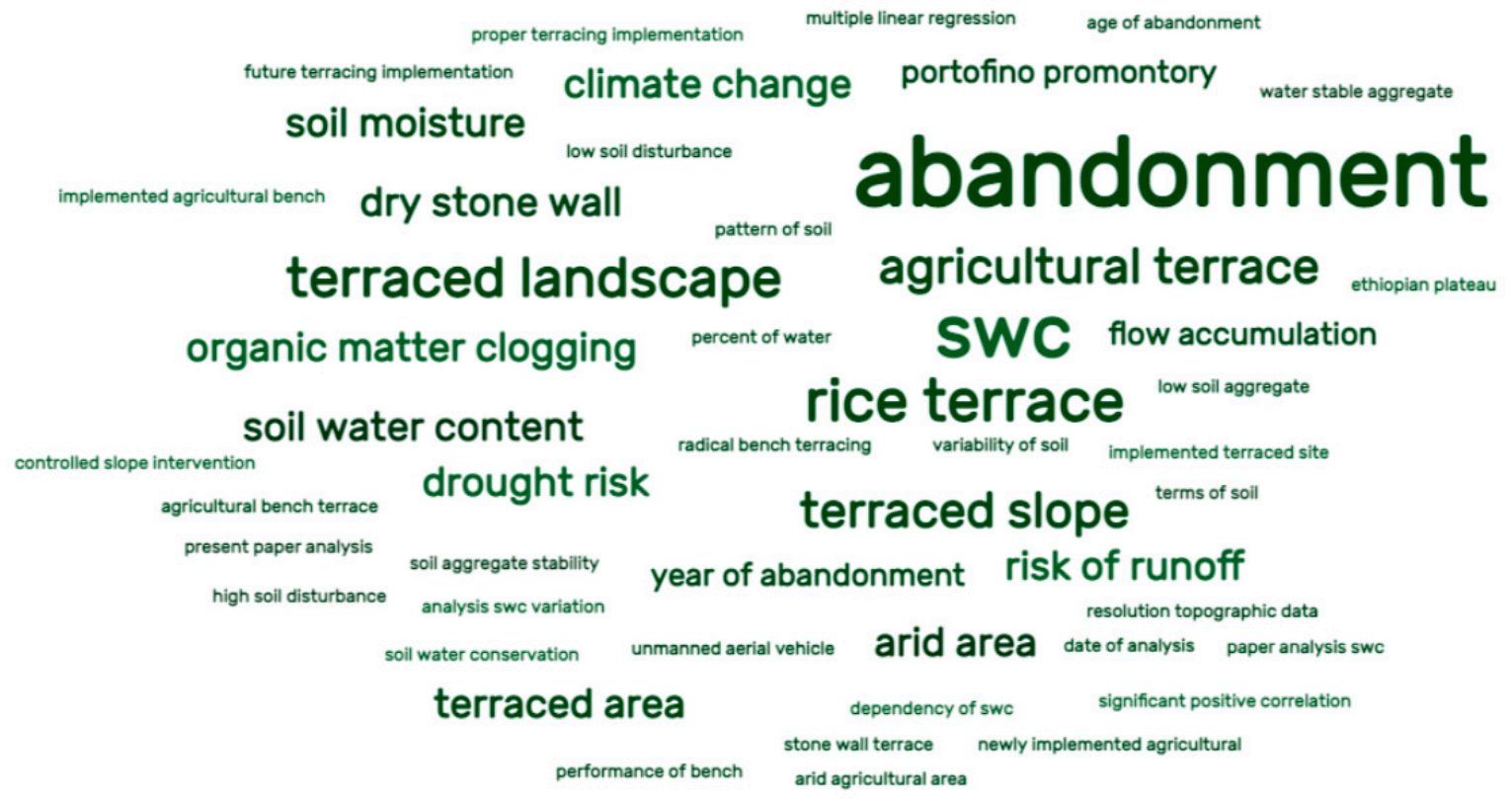

Figure 3. Word cloud generated from titles, keywords, and abstracts of the Special Issue, with the most frequent words in the largest font. "Abandonment" was the most frequent term, with 20 occurrences.

Remote sensing emerged as one of the most promising technological advances, joint with the use of morphological indexes [13,15,19]. Such a tendency is not new [21], but recent advancements in remote sensing technologies have allowed a rapid evolution leading to multiple innovative applications [22], including low-cost [19] and quick and effective uses [13].

Some of the papers presented in the Special Issue also highlighted the importance of advanced hydrological analyses at the terraced landscape scale $[14,18,20]$. Such approaches are not frontier research, but the papers submitted considered different and heterogeneous case studies (Moroccan Anti-Atlas, Ethiopian and Philippine rice terraces), which were understudied under this point of view, and which therefore could be further explored. Finally, as highlighted also by Boselli et al. [17], innovative socio-ecological frameworks should be put in place for the analysis of the evolution of terraced agroecosystems, in order to shed light on the relationship between social dynamics and hydrological and geological hazards, which are definitively intertwined.

Author Contributions: Writing—original draft preparation, G.C.; writing—review and editing, G.C., A.E., F.P.; supervision, F.P., G.C. All authors have read and agreed to the published version of the manuscript.

Funding: This research received no external funding.

Acknowledgments: The authors are grateful to Water MDPI for the possibility of developing the Special Issue "Terraced Landscapes and Hydrological-Geological Hazards". We thank all the scholars who contributed as authors and reviewers to the Issue, including those who had their paper rejected. We are grateful also to Daniele Penna and Paolo Tarolli for the critical reading and for the suggestions for the present Editorial.

Conflicts of Interest: The authors declare no conflict of interest. 


\section{References}

1. Tarolli, P. Agricultural Terraces Special Issue Preface. Land Degrad. Dev. 2018, 29, 3544-3548. [CrossRef]

2. Wei, W.; Chen, D.; Wang, L.; Daryanto, S.; Chen, L.; Yu, Y.; Lu, Y.; Sun, G.; Feng, T. Global synthesis of the classifications, distributions, benefits and issues of terracing. Earth-Sci. Rev. 2016, 159, 388-403. [CrossRef]

3. Deng, C.; Zhang, G.; Liu, Y.; Nie, X.; Li, Z.; Liu, J.; Zhu, D. Advantages and disadvantages of terracing: A comprehensive review. Int. Soil Water Conserv. Res. 2021, 9, 344-359. [CrossRef]

4. Preti, F.; Guastini, E.; Penna, D.; Dani, A.; Cassiani, G.; Boaga, J.; Deiana, R.; Romano, N.; Nasta, P.; Palladino, M.; et al. Conceptualization of Water Flow Pathways in Agricultural Terraced Landscapes. Land Degrad. Dev. 2018, 29, 651-662. [CrossRef]

5. Arnáez, J.; Lana-Renault, N.; Lasanta, T.; Ruiz-Flaño, P.; Castroviejo, J. Effects of farming terraces on hydrological and geomorphological processes. A review. Catena 2015, 128, 122-134. [CrossRef]

6. Agnoletti, M.; Errico, A.; Santoro, A.; Dani, A.; Preti, F. Terraced landscapes and hydrogeological risk. Effects of land abandonment in Cinque Terre (Italy) during Severe rainfall events. Sustainability 2019, 11, 235. [CrossRef]

7. Tarolli, P.; Preti, F.; Romano, N. Terraced landscapes: From an old best practice to a potential hazard for soil degradation due to land abandonment. Anthropocene 2014, 6, 10-25. [CrossRef]

8. Pijl, A.; Quarella, E.; Vogel, T.A.; Agostino, V.D.; Tarolli, P. Remote sensing vs. field-based monitoring of agricultural terraces degradation. Int. Soil Water Conserv. Res. 2021, 9, 1-10. [CrossRef]

9. Camera, C.; Djuma, H.; Bruggeman, A.; Zoumides, C.; Eliades, M.; Charalambous, K. Quantifying the effectiveness of mountain terraces on soil erosion protection with sediment traps and dry-stone wall laser scans. Catena 2018, 171, 251-264. [CrossRef]

10. Coppola, A.; Abdallah, M.; Dragonetti, G.; Zdruli, P.; Lamaddalena, N. Monitoring and modelling the hydrological behaviour of a reclaimed wadi basin in Egypt. Ecohydrology 2019, 12, e2084. [CrossRef]

11. Ben Khelifa, W.; Strohmeier, S.; Benabdallah, S.; Habaieb, H. Evaluation of bench terracing model parameters transferability for runoff and sediment yield on catchment modelling. J. Afr. Earth Sci. 2021, 178, 104177. [CrossRef]

12. Stavi, I.; Gusarov, Y.; Halbac-Cotoara-Zamfir, R. Collapse and failure of ancient agricultural stone terraces: On-site geomorphic processes, pedogenic mechanisms, and soil quality. Geoderma 2019, 344, 144-152. [CrossRef]

13. Pijl, A.; Tosoni, M.; Roder, G.; Sofia, G.; Tarolli, P. Design of terrace drainage networks using UAV-based high-resolution topographic data. Water 2019, 11, 814. [CrossRef]

14. Mesfin, S.; Oliveira, L.A.A.; Yazew, E.; Bresci, E.; Castelli, G. Spatial variability of soil moisture in newly implemented agricultural bench terraces in the Ethiopian plateau. Water 2019, 11, 2134. [CrossRef]

15. Paliaga, G.; Luino, F.; Turconi, L.; De Graff, J.V.; Faccini, F. Terraced Landscapes on Portofino Promontory (Italy): Identification, Geo-Hydrological Hazard and Management. Water 2020, 12, 435. [CrossRef]

16. Berčič, T.; Ažman-Momirski, L. Parametric terracing as optimization of controlled slope intervention. Water 2020, $12,634$. [CrossRef]

17. Boselli, V.; Ouallali, A.; Briak, H.; Houssni, M.; Kassout, J.; El Ouahrani, A.; Michailidi, E.M. System dynamics applied to terraced agroecosystems: The case study of assaragh (Anti-Atlas Mountains, Morocco). Water 2020, 12, 1693. [CrossRef]

18. Kurozumi, T.; Mori, Y.; Somura, H.; O-How, M. Organic matter clogging results in undeveloped hardpan and soil mineral leakage in the rice terraces in the Philippine cordilleras. Water 2020, 12, 3158. [CrossRef]

19. Cambi, M.; Giambastiani, Y.; Giannetti, F.; Nuti, E.; Dani, A.; Preti, F. Integrated low-cost approach for measuring the state of conservation of agricultural terraces in tuscany, Italy. Water 2021, 13, 113. [CrossRef]

20. Sabir, M. The terraces of the anti-atlas: From abandonment to the risk of degradation of a landscape heritage. Water 2021, 13, 510. [CrossRef]

21. Tarolli, P.; Sofia, G.; Calligaro, S.; Prosdocimi, M.; Preti, F.; Dalla Fontana, G. Vineyards in Terraced Landscapes: New Opportunities from Lidar Data. Land Degrad. Dev. 2015, 26, 92-102. [CrossRef]

22. Tucci, G.; Parisi, E.I.; Castelli, G.; Errico, A.; Corongiu, M.; Sona, G.; Viviani, E.; Bresci, E.; Preti, F. Multi-sensor UAV application for thermal analysis on a dry-stone terraced vineyard in rural Tuscany landscape. ISPRS Int. J. Geo-Inf. 2019, 8, 87. [CrossRef] 